\title{
Ministernotomy or sternotomy in isolated aortic valve replacement? Early results
}

\author{
Grzegorz Filip ${ }^{1}$, Magdalena A. Bryndza르, Janusz Konstanty-Kalandyk ${ }^{1}$, Jacek Piatek ${ }^{1}$, Piotr Wegrzyn ${ }^{1}$, \\ Piotr Ceranowicz ${ }^{2}$, Maciej Brzezinski ${ }^{3}$, Dhanunjaya Lakkireddy ${ }^{4}$, Boguslaw Kapelak ${ }^{1}$, Krzysztof Bartuś ${ }^{1}$
}

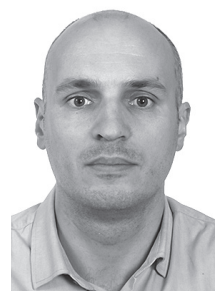

${ }^{1}$ Department of Cardiovascular Surgery and Transplantology, Jagiellonian University, John Paul II Hospital, Krakow, Poland ${ }^{2}$ Department of Physiology, Jagiellonian University, Krakow, Poland

${ }^{3}$ Department of Cardiac and Vascular Surgery, Medical University of Gdansk, Gdansk, Poland

${ }^{4}$ The Kansas City Heart Rhythm Institute, Overland Park Regional Hospital, Overland Park, Kansas, USA

Kardiochirurgia i Torakochirurgia Polska 2018; 15 (4): 213-218

\begin{abstract}
Introduction: Aortic valve replacement (AVR) is the gold standard in treating symptomatic aortic valve defects. To improve the healing process and limit the trauma, the minimally invasive approach was introduced.

Aim: To compare the peri- and post-operative results of aortic valve replacement performed via conventional full sternotomy (con-AVR) and of AVR performed via partial upper sternotomy (mini-AVR).

Material and methods: The total study population was divided into 2 demographically homogeneous groups: mini-AVR $(n=74)$ and con-AVR $(n=76)$. There were no statistically significant differences in preoperative echocardiography.

Results: Aortic cross-clamp time and cardiopulmonary bypass time were significantly longer in the mini-AVR group. Shorter mechanical ventilation time, hospital stay and lower postoperative drainage were observed in the mini-AVR group $(p<0.05)$. Biological prostheses were more frequently implanted in the mini-AVR group $(p<0.05)$. Patients from the mini-AVR group reported less postoperative pain. No significant differences were found in the diameter of the implanted aortic prosthesis, the amount of inotropic agents and painkillers, postoperative left ventricular ejection fraction (LVEF), medium and maximum transvalvular gradient or the number of transfused blood units. There were no differences in the frequency of postoperative complications such as mortality, stroke, atrial fibrillation, renal failure, wound infection, sternal instability, or the need for rethoracotomy.

Conclusions: Ministernotomy for AVR is a safe method and does not increase morbidity and mortality. It significantly reduces post-operative blood loss and shortens hospital stay. Ministernotomy can be successfully used as an alternative method to sternotomy.
\end{abstract}

Key words: ministernotomy, aortic valve replacement, miniaortic valve replacement, sternotomy.

\section{Streszczenie}

Wprowadzenie: Chirurgiczna wymiana zastawki aortalnej (AVR) jest złotym standardem leczenia objawowych wad zastawki aortalnej. Małoinwazyjny dostęp chirurgiczny pomaga zminimalizować uszkodzenie tkanek oraz usprawnia procesy gojenia rany pooperacyjnej.

Cel: Porównanie okołooperacyjnych oraz pooperacyjnych wyników leczenia AVR wykonywanej przez sternotomię pośrodkową (con-AVR) oraz poprzez częściową sternotomię górną (mini-AVR). Materiat i metody: Pacjentów włączonych do badania podzielono na dwie demograficznie homogenne grupy: mini-AVR $(n=74)$ i con-AVR $(n=76)$. Nie było różnic między grupami w wynikach przedoperacyjnego badania echokardiograficznego. Wyniki: Czas zakleszczenia aorty i czas krążenia pozaustrojowego były dłuższe w grupie mini-AVR, w której obserwowano również krótszy czas wentylacji mechanicznej i hospitalizacji oraz mniejszy drenaż pooperacyjny $(p<0,05)$. W grupie mini-AVR częściej wszczepiano zastawki biologiczne. Pacjenci z grupy mini-AVR zgłaszali niższe natężenie bólu po operacji $(p<0,05)$. Nie obserwowano istotnych statystycznie różnic pod względem średnicy implantowanych zastawek, stosowanych leków inotropowych, leków przeciwbólowych, pooperacyjnej frakcji wyrzutowej, średnich i maksymalnych gradientów zastawkowych oraz ilości przetaczanej krwi pomiędzy grupami. Nie stwierdzono również różnic w występowaniu komplikacji pooperacyjnych, takich jak zgon, udar, migotanie przedsionków, niewydolność nerek, infekcje rany, niestabilność mostka i powtórne otwarcie klatki piersiowej.

Wnioski: Ministernotomia jest bezpiecznym dostępem chirurgicznym podczas AVR, który nie zwiększa ryzyka wystąpienia powikłań, w tym zgonu. Mini-AVR znacząco zmniejsza pooperacyjną utratę krwi i skraca czas pobytu w szpitalu. Może być z sukcesem stosowana jako alternatywa dla pełnej sternotomii.

Słowa kluczowe: ministernotomia, wymiana zastawki aortalnej, małoinwazyjna wymiana zastawki aortalnej, sternotomia.

Address for correspondence: Magdalena A. Bryndza MD, Department of Cardiovascular Surgery and Transplantology, Jagiellonian University, John Paul II Hospital, 80 Prądnicka St, 31-202 Krakow, Poland, phone: +48 1261432 03, e-mail: bryndzamagdalena@gmail.com Received: 17.05.2018, accepted: 1.09.2018. 


\section{Introduction}

Aortic valve malformation is the fourth most common cardiovascular problem in the modern world, affecting $2-7 \%$ of patients aged 65 or older [1]. The most common type of defect is aortic stenosis mainly caused by valve degeneration. If left untreated, it leads to myocardial hypertrophy and prolongation of left ventricular ejection time, which causes deterioration of contractility, left ventricular size enlargement and increase of end-diastolic pressure. Pharmacological treatment helps to relieve symptoms, but still aortic valve replacement (AVR) is the standard treatment for hemodynamically significant aortic valve disease.

In recent years, two approaches have emerged in surgical aortic valve replacement: full conventional sternotomy (con-AVR) and minimally invasive aortic valve replacement (mini-AVR). Compared to con-AVR, the mini-AVR approach is technically challenging and more demanding with a reduced surgical field. Limited access to the heart and a smaller operative field may increase the surgical risk. On the other hand, mini-AVR shows better cosmetic effects, a lower level of postoperative pain, shorter intensive care unit (ICU) stay, and generally shorter hospitalization. However, there is no clear superiority of either approach [2-5].

\section{Aim}

The aim of the study was to compare the early outcomes of aortic valve replacement performed through conventional full sternotomy (con-AVR) and of AVR through less invasive J-shaped hemisternotomy (mini-AVR).

\section{Material and methods}

A retrospective, single-center study was performed in patients undergoing isolate surgical aortic valve replacement. Inclusion and exclusion criteria are shown in Table I. Patients were divided into two groups depending on the procedure approach: mini-AVR and con-AVR.

\section{Surgical technique}

In each group, con-AVR and mini-AVR, all procedures were performed by a group of four experienced surgeons. In each case, the decision on the method used and on the prosthesis type and size was made by the implanting surgeon. No aortic annulus enlargement techniques were used.

Minimally invasive aortic valve replacement was performed via a 7-8 cm skin incision from the level of the head of the second rib in the midline over the sternum and down to the level of the head of the fourth intercostal space. The reserved J-shaped approach was obtained by making an incision along the mid-line of the sternum from the jugular notch to the fourth intercostal space.

Conventional sternotomy was approached by traditional median sternotomy, which was followed by aortic and right atrium cannulation with vacuum suction.

Cold-crystalloid or cold-blood cardioplegic solution was administered anterogradely, and then retrogradely every 20 min after opening the aorta.

\section{Statistical analysis}

Values are given as mean \pm standard deviation. The Shapiro-Wilk test was performed to determine the normal distribution. To compare continuous variables between groups that had a normal distribution, an independent t-test was used. Continuous variables that did not exhibit a normal distribution were compared with the Mann-Whitney $U$-test. All dichotomous variables were compared using $\chi^{2}$ analysis or the Kolmogorov-Smirnov test. A $p$-value of less than 0.05 was considered statistically significant. Statistical analysis was performed using Statistica 10 software (StatSoft Inc., Tulsa, OK, USA).

\section{Results}

A total of 150 patients were enrolled in the study: 74 patients who underwent mini-AVR and 76 patients who un-

Table I. Inclusion and exclusion criteria

\begin{tabular}{|c|c|}
\hline Inclusion criteria & Exclusion criteria \\
\hline $\begin{array}{l}\text { - Age } \geq 18 \\
\text { - Caucasian race } \\
\text { - Symptomatic aortic valve defect requiring cardiac surgery } \\
\text { - Echocardiographic diagnosis of isolated aortic valve } \\
\text { malformation: aortic stenosis, aortic insufficiency, combined } \\
\text { defect of aortic valve } \\
\text { - Current New York Heart Association (NYHA) stage } \geq 1 \\
\text { - Life expectancy } \geq 1 \text { year }\end{array}$ & $\begin{array}{l}\text { - Previous cardiac surgery } \\
\text { - Defects of other heart valves requiring surgical correction } \\
\text { - Myocardial infarction or unstable angina in previous } 3 \text { months } \\
\text { - Coexisting ischemic heart disease requiring coronary artery bypass } \\
\text { grafting (CABG) } \\
\text { - Current right ventricular heart insufficiency } \\
\text { - Current cardiogenic shock on hemodynamic instability } \\
\text { - Need for intra-aortic counterpulsation or inotropic agents intravenously } \\
\text { - Need for urgent operation } \\
\text { - Current or previous endocarditis } \\
\text { - Left ventricular ejection fraction (LVEF) < 30\% } \\
\text { - Previous thoracic injury } \\
\text { - Deformation of the thorax } \\
\text { - Severe scoliosis } \\
\text { - Current systemic infection } \\
\text { - Diagnosed autoimmune disease with known association with } \\
\text { - pericarditis (e.g. collagenosis) } \\
\text { - } \text { undental retardation or another disease which may preclude } \\
\text { - Devere stage of chronic obstructive pulmonary disease (COPD) } \\
\text { Diagnod cancer limiting survival below } 12 \text { months }\end{array}$ \\
\hline
\end{tabular}


derwent con-AVR. Baseline characteristics are summarized in Table II. Patients were matched for age, body mass index (BMI), gender and comorbidities. Preoperative transthoracic echocardiography results are summarized in Table III. Groups were similar for type of valve pathology, valve type, left ventricular ejection fraction (LVEF), maximal and mean aortic gradient, indexed aortic valve area (iAVA), left ventricular posterior wall (LVPW) and intraventricular septum (IVS). In the mini-AVR group mean aortic gradient was $71.6 \pm 22.8 \mathrm{~mm} \mathrm{Hg}$ and was higher as compared to con-AVR, $53.0 \pm 20.5 \mathrm{~mm} \mathrm{Hg}$.

\section{Procedure parameters}

In the mini-AVR group aortic cross-clamp time (ACC), cardiopulmonary bypass time (CBP) and total operation time were longer than in the con-AVR group. All differences between groups were statistically significant (Table IV).

\section{Type of prosthesis and diameters}

In the mini-AVR group, 3 (4\%) patients had an ATS mechanical aortic valve implanted, while 71 (96\%) patients received a biological aortic prosthesis. As many as 51 patients had a Carpentier-Edwards Perimount valve implanted and another 20 had a Medtronic Hancook II. In the AVR group, a mechanical prosthesis was implanted in 17 (22\%) patients, an ATS in 9 patients and a St. Jude Medical Master in 8 patients. In the con-AVR group a biological prosthesis was implanted in 59 (78\%) patients, a Carpentier-Edwards Perimount valve in 44 patients, and a Medtronic Hancook II in 15 patients. The differences were statistically significant $(p=0.006)$ (Fig. 1).

In the mini-AVR group, the median prosthesis diameter was $23 \mathrm{~mm}(21-25 \mathrm{~mm})$ and in the con-AVR group it was $23 \mathrm{~mm}$ (23-25 mm) (Fig. 2). No statistically significant difference was observed in aortic prosthesis diameter or approach used during the operation $(p>0.05)$.

Postoperative transthoracic echocardiography examination in the mini-AVR group showed LVEF of $50 \%$ (38$50 \%)$, maximal aortic gradient of $24 \mathrm{~mm} \mathrm{Hg}(19-29 \mathrm{~mm} \mathrm{Hg})$ and mean aortic gradient of $14 \mathrm{~mm} \mathrm{Hg}$ (11-18 mm Hg). In the con-AVR group LVEF was 45\% (30-49\%), maximal aortic gradient was $24 \mathrm{~mm} \mathrm{Hg}(16-28 \mathrm{~mm} \mathrm{Hg})$ and mean aortic gradient was $12 \mathrm{~mm} \mathrm{Hg}$ (9-17 mm Hg). Differences were statistically insignificant $(p>0.05)$.

\section{Clinical outcomes}

In the mini-AVR group 41 (57\%) patients received inotropic drugs and in the con-AVR group 51 (63\%) patients did. The difference was statistically insignificant $(p>0.05)$. In the mini-AVR group median time of mechanical ventilation was 8 (6-14) $\mathrm{h}$ and for the con-AVR group the median time was $10(6-18) h$. The difference was statistically significant $(p=0.045)$. To assess postoperative pain, the Numerical Rating Scale (NRS) 0-10 was used. In the mini-AVR group, the intensity of pain was lower in comparison to the con-AVR group and the result was statistically significant
Table II. Demographic and comorbidity data

\begin{tabular}{|c|c|c|c|}
\hline Parameter & Mini-AVR & Con-AVR & $P$-value \\
\hline \multicolumn{3}{|l|}{ Gender: } & \multirow{3}{*}{$>0.05$} \\
\hline Female & $47.3 \%(35)$ & $38.2 \%(29)$ & \\
\hline Male & $52.7 \%(39)$ & $61.8 \%(47)$ & \\
\hline Age [years] & $68(57-77)$ & $66(52-73)$ & $>0.05$ \\
\hline BMI $\left[\mathrm{kg} / \mathrm{m}^{2}\right]$ & $28.21 \pm 4.36$ & $28.28 \pm 5.46$ & $>0.05$ \\
\hline EuroSCORE & $7(3-10)$ & $7(3-11)$ & $>0.05$ \\
\hline NYHA: & $2(2-3)$ & $2(2-3)$ & \multirow[t]{5}{*}{$>0.05$} \\
\hline NYHA I & $7.6 \%$ & $24.5 \%$ & \\
\hline NYHA II & $51.5 \%$ & $40.8 \%$ & \\
\hline NYHA III & $39.4 \%$ & $34.7 \%$ & \\
\hline NYHA IV & $1.5 \%$ & $0 \%$ & \\
\hline CCS: & $2(1-2)$ & $1(1-2)$ & \multirow[t]{5}{*}{0.007} \\
\hline $\operatorname{cCS} 0$ & $1.5 \%$ & $19.1 \%$ & \\
\hline CCSI & $40.0 \%$ & $44.7 \%$ & \\
\hline CCS II & $46.2 \%$ & $29.8 \%$ & \\
\hline CCS III & $12.3 \%$ & $6.4 \%$ & \\
\hline History of MI & $23.3 \%$ & $38.6 \%$ & $>0.05$ \\
\hline Previous $\mathrm{PCl}$ & $9.6 \%$ & $19 \%$ & $>0.05$ \\
\hline Diabetes mellitus type II & $23 \%$ & $17 \%$ & $>0.05$ \\
\hline Obesity & $38 \%$ & $25 \%$ & $>0.05$ \\
\hline Hypertension & $67.5 \%$ & $67 \%$ & $>0.05$ \\
\hline Atrial fibrillation & $24.3 \%$ & $17.2 \%$ & $>0.05$ \\
\hline Peripheral vessel disease & $16 \%$ & $12 \%$ & $>0.05$ \\
\hline COPD & $8 \%$ & $7 \%$ & $>0.05$ \\
\hline History of stroke & $3 \%$ & $8 \%$ & $>0.05$ \\
\hline
\end{tabular}

Table III. Preoperative transthoracic echocardiography results

\begin{tabular}{|c|c|c|c|}
\hline Parameter & Mini-AVR & Con-AVR & $P$-value \\
\hline \multicolumn{3}{|l|}{ Type of aortic defect: } & \multirow{4}{*}{$>0.05$} \\
\hline Stenosis & $77 \%$ & $75.9 \%$ & \\
\hline Aortic insufficiency & $8.1 \%$ & $19.0 \%$ & \\
\hline Combined defect $(S A+I A)$ & $14.9 \%$ & $5.2 \%$ & \\
\hline Bicuspid valve & $76.4 \%$ & $71.7 \%$ & $>0.05$ \\
\hline LVEF (\%) & $60(52-63)$ & $60(55-65)$ & $>0.05$ \\
\hline Max. gradient [mm Hg] & $98(78-110)$ & $95(75-100)$ & $>0.05$ \\
\hline Mean gradient [mm Hg] & $71.6 \pm 22.8$ & $53 \pm 20.5$ & 0.002 \\
\hline iAVA $\left[\mathrm{cm}^{2} / \mathrm{m}^{2}\right]$ & $0.8(0.6-1.2)$ & $0.5(0.5-0.8)$ & $>0.05$ \\
\hline LVPW [cm] & $1.4(1.2-1.6)$ & $1.3(1.2-1.6)$ & $>0.05$ \\
\hline IVS [cm] & $1.5(1.4-1.7)$ & $1.5(1.3-1.6)$ & $>0.05$ \\
\hline
\end{tabular}

Table IV. Comparison of ACC, CBP and total operation time depending on used approach

\begin{tabular}{lccc} 
Parameter & Mini-AVR & Con-AVR & P-value \\
ACC [min] & $75(64-87)$ & $55(50-63)$ & $<0.001$ \\
\hline CBP [min] & $127(116-140)$ & $97(90-123)$ & $<0.001$ \\
\hline $\begin{array}{l}\text { Total operation } \\
\text { time [min] }\end{array}$ & $240(210-240)$ & $200(180-230)$ & $<0.001$ \\
\hline
\end{tabular}




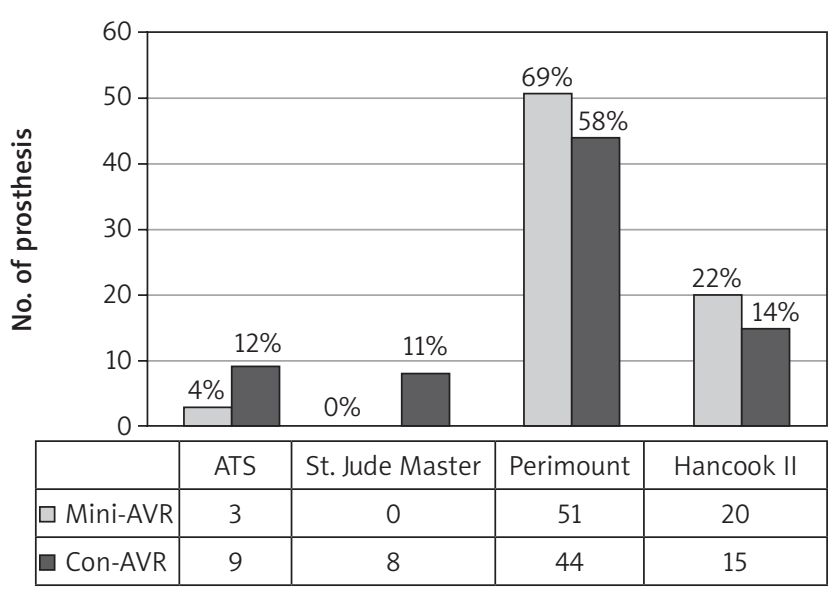

Fig. 1. Type of prosthesis depending on surgical approach groups (ministernotomy vs. sternotomy) $(p=0.006)$

$(p<0.05)$. No statistically significant differences were observed between groups for time of use of any analgesics: opioids, paracetamol, or NSAIDs. No statistically significant differences were observed in the level of postoperative hemoglobin between groups; the median for mini-AVR was 10.5 (10.1-1.4) g/dl and for con-AVR 10.3 (9.6-11.2) g/dl. Median postoperative drainage in the mini-AVR group was 360 (130-1300) $\mathrm{ml}$ and was lower than in the con-AVR group, with the median of $590(180-2300) \mathrm{ml}(p<0.001)$. No statistically significant difference was observed in the amount of patients requiring transfusion of red cell concentrate $(27 \%$ of patients in the mini-AVR group vs. $34 \%$ in the con-AVR group). In the mini-AVR group, the frequency of transfusion of fresh frozen plasma (FFP) was $15 \%$ and was statistically significantly lower than in the group of con-AVR patients, where it was $32 \%(p=0.01)$. In the mini-AVR group, $9 \%$ of patients needed platelet concentrate transfusion and in the con-AVR group $18 \%$. No statistically significant differences in the number of deaths or the length of ICU stay were observed. The in-hospital stay was statistically significantly $(p=0.02)$ longer in the group of con-AVR patients and averaged 8 days in comparison to 7 days in the case of mini-AVR patients. In the mini-AVR group one person was diagnosed with acute kidney injury requiring hemodialysis. No strokes were observed in the whole study. No significant differences were observed in the frequency of postoperative AF (9.4\% in mini-AVR vs. $19.7 \%$ in con-AVR), the need for repeated suturing of the sternum $(1.3 \%$ in mini-AVR vs. $5.2 \%$ in con-AVR group), or the amount of surgical reinterventions due to bleeding procedures $(1.3 \%$ in mini-AVR vs. $5.2 \%$ in con-AVR).

\section{Discussion}

Over the past years, less invasive approaches have become more popular in cardiac surgery of adults.

As compared to sternotomy, ministernotomy is less traumatic, provides better stability of the sternum and thorax, accelerates the healing process and ensures a better cosmetic effect with fewer deep sternal wound complica-

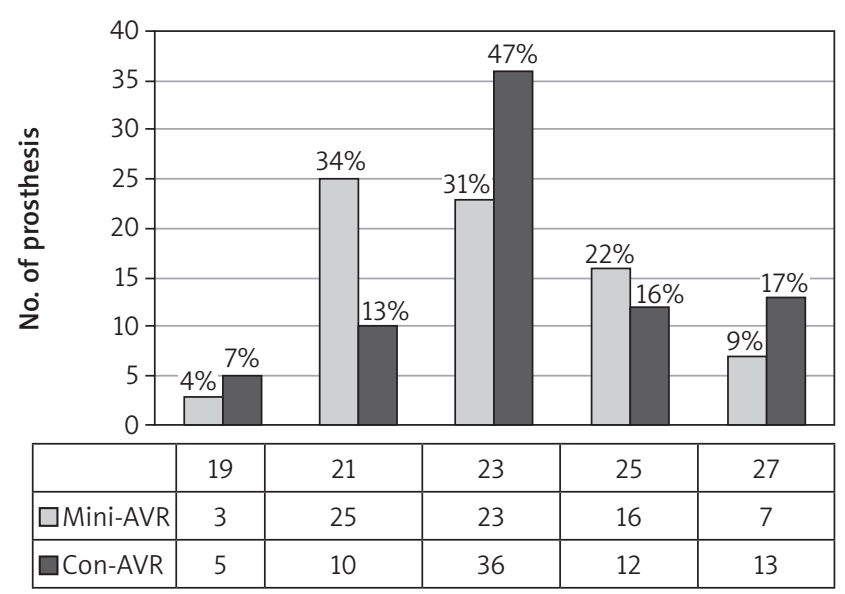

Fig. 2. Diameter of implanted prosthesis depending on used approach $(p>0.05)$

tions [6]. Additionally, ministernotomy appears to be the safest of all minimally invasive methods, because it can be easily converted to full sternotomy. Also, patients tend to choose a less invasive method, if possible. However, there are some limitations of ministernotomy: it restricts access to the ascending aorta, limits the operation field and impedes visualization for the operator and assistant surgeon during the whole operation. It may also prolong the time of the operation. Because of that, mini-AVR is technically more demanding for a cardiac surgeon and requires more experience and abilities. There are many controversies concerning the advantages and disadvantages of mini-AVR in the current literature.

Prolonged ACC, CPB and total operation time are considered to be among the biggest disadvantages of the mini-AVR technique. Some authors believe that prolongation of CPB and ACC puts patients at risk of complications, which could have been avoided with classic sternotomy. In addition, partial cutting of the sternum results in difficulties in the assessment of contractility of myocardium, ventricular refill and problems with venting the heart [7]. It was proven that prolonged ACC and CPB are independent risk factors of cardiovascular complications such as low cardiac output, stroke, acute kidney injury and increased risk of perioperative death. Ranucii et al. reported that $1 \mathrm{~min}$ of ACC in patients undergoing AVR is an independent risk factor increasing the risk of cardiovascular complications [8]. A study conducted by Salis et al. showed that prolonging CPB for over 30 min also increases the risk of that complication [9]. In addition, some authors believe that prolonged CPB causes a systemic inflammatory reaction, which may lead to multiorgan failure [10]. Brown et al. demonstrated in their meta-analysis that the parameters CPB, ACC and total operation time are significantly longer for ministernotomy than for sternotomy. For ACC, the weighted mean difference was $7.9 \mathrm{~min}$ (3.5-12.3 $\mathrm{min}$ ), for CPB $11.46 \mathrm{~min}$ (5.26-17.65 min), and for total operation time $1.58 \mathrm{~min}$ (2.7-28.46 min) [2]. In our study, ACC, CPB and operation time were similar to the results found in the literature. 
A compensatory mechanism in aortic valve defects causes left ventricular hypertrophy (LVH), which is an independent risk factor of cardiovascular complications and sudden cardiac death. The LVH increases the risk of stroke, ischemic heart disease occurrence and peripheral vascular disease and may cause ventricular arrhythmias. The risk increases even more if LVH coexists with aortic stenosis. Research by Lund et al. showed that the lack of left ventricular hypertrophy reduction after AVR significantly reduces the 10-year survival [11]. In the case of improper fit of the prosthesis to the patient's body surface area there is a risk of incomplete paravalvular gradient reduction after the operation and patient-prosthesis mismatch (PPM) occurrence. A previous study showed that PPM is more common after ministernotomy than sternotomy [12]. Increased transvalvular gradient leads to faster degeneration of an implanted biological prosthesis, which causes sooner reoperation and worsens the survival rate [13].

In contrast to the CABG procedure, in patients undergoing AVR, left ventricular contractility disorders do not resolve after the operation. In patients with normal preoperative left ventricular systolic function contractility disorders may occur in 4-6 h after the operation and usually subside in $24 \mathrm{~h}$. Therefore, in the postoperative period, inotropic drugs are indicated. Factors that may increase the need for inotropic drugs are the following: elderly age, cardiomegaly, sex, reduced ejection fraction, urgency of the operation, previous MI, prolonged ACC or CPB [14-16]. As it was shown in our study, ACC and CPB are longer in ministernotomy AVR procedures. So far, only Szwerc et al. have investigated the influence of ACC and CBP and found that in patients after ministernotomy the need for inotropic drugs was higher than in patients after sternotomy, but their study showed no difference in the length of CPB and ACC [17]. In our study there was no statistically significant difference in inotropic drug supply. Inotropic drugs were used when clinical signs of heart failure occurred. There are no guidelines on the treatment of contractility disorders in our center; thus the decision on inotropic drug therapy is a subjective decision of the surgeon or ICU physician and it is not dependent on the approach used.

Respiratory failure and prolonged mechanical ventilation in patients after cardiac surgery operations constitute a very important factor increasing the risk of perioperative death and in-hospital readmission to the ICU [18]. The frequency of respiratory failure after cardiac surgery is estimated at 5-20\% [19]. In the literature the mechanical ventilation time was significantly shorter in the mini-AVR group than in the AVR group and the frequency of respiratory failure was statistically lower in the mini-AVR group $[3,5,20]$. In our study, the median time of mechanical ventilation was statistically significantly shorter for the miniAVR group than for the AVR group. Moreover, between the analyzed groups there was no difference in the frequency of respiratory diseases, which might have influenced the results. The ministernotomy approach decreases postoperative mechanical ventilation time and diminishes the risk of respiratory failure in the mini-AVR group.
The influence of ministernotomy on the reduction of postoperative bleeding remains unclear. The majority of publications conclude that postoperative drainage is significantly lower in mini-AVR patients than in AVR patients. However, postoperative blood loss depends not only on surgical approaches or surgeon experience but also on various other factors such as preoperative medications or coagulopathy [5, 20-22].

In our study, the median drainage was $230 \mathrm{ml}$ lower in ministernotomy than in sternotomy procedures. Ministernotomy reduces postoperative bleeding because it causes less trauma to the tissue and a smaller inflammatory response [10]. When assessing postoperative blood loss with the amount of transfusions, investigators can avoid error resulting from use of anticoagulation drugs, extracorporeal circulation (ECC) and operation time length. Only one study showed lower incidence of blood transfusions in the miniAVR group, but the amount of units transfused was practically equal in both groups. In our study and many other papers, there were no differences in the number of blood units, transfused blood volume, or number of patients requiring transfusion [3, 17, 20, 23]. However, because there is no uniform blood transfusion scheme after cardiac procedures at our center, the time from operation to transfusion, and the number of transfused blood units, can be different and does not constitute a perfect method of postoperative blood loss estimation. Additionally, postoperative blood loss does not depend only on surgical approaches or surgeon experience, but is also a result of other factors such as preoperative treatment or coagulopathy [5, 20-22]. Therefore, interpretation and comparison of the results is difficult. We conclude that ministernotomy does not reduce the need for blood transfusion, but reduces postoperative drainage because of reduced tissue damage and production of inflammatory factors.

Several studies have confirmed that patients after miniAVR experienced less pain than patients after con-AVR. Bonacchi et al. observed lower intake of morphine during the first $12 \mathrm{~h}$ after the operation and lower intake of NSAIDs in the first $72 \mathrm{~h}$ [3]. In our study we observed statistically significantly lower pain intensity on the NRS scale in the group of mini-AVR, but no differences in the length of painkiller intake.

The length of ICU stay and hospital stay were shorter in the mini-AVR group according to many authors [3, 20]. In our study, data were similar but we achieved a statistically significant result only for the length of hospital stay. We did not observe a statistically significant difference in in-hospital mortality between groups, similarly to previous studies [3-5].

In this paper, the major complications were analyzed and the results were compared to the literature. Results concerning postoperative AF are unclear; some authors stated that mini- AVR may have a higher risk of that arrhythmia, but others reported a lower risk [3, 24]. In our study we observed a statistically insignificantly lower frequency of AF in the mini-AVR group. We did not observe 
stroke in the whole study. However, it should be noted that during the AVR procedure, left atrial appendage closure may be performed to prevent thromboembolic complications with surgical techniques or dedicated devices [25].

Only 1 case of acute kidney injury and hemodialysis therapy was observed, and the patient underwent miniAVR. In the literature, no significant association was observed [24]. The frequency of resternotomy procedure, sternal dehiscence, and the need for repeated suturing of the sternum was lower in the mini-AVR group, but the difference was not statistically significant. Observations of other authors are similar [3, 24].

\section{Conclusions}

Basing on our observations and literature review we conclude that ministernotomy is a safe approach to perform aortic valve replacement. It may be used as an alternative to full sternotomy, but requires more experience than the classic approach. Observations show that postoperative outcomes are comparable or even better for the mini-AVR group in comparison to the AVR group. Ministernotomy may reduce the costs of the hospitalization by shortening the in-hospital stay. Also patients' choice is a very important aspect, as patients would prefer less pain and a better cosmetic effect. Therefore, ministernotomy seems to be a valuable option for our patients.

\section{Acknowledgments}

The study was granted with the program "Diamond Grant" founded by the Ministry of Science and Higher Education for years 2016-2018.

\section{Disclosure}

The authors report no conflict of interest.

\section{References}

1. Members ATF, Vahanian A, Alfieri O, Andreotti F, Antunes MJ, Barón-Esquivias G, Baumgartner H, Borger MA, Carrel TP, De Bonis M. Guidelines on the management of valvular heart disease (version 2012) The Joint Task Force on the Management of Valvular Heart Disease of the European Society of Cardiology (ESC) and the European Association for Cardio-Thoracic Surgery (EACTS). Eur J Cardio thor Surg 2012; 42: S1-S44.

2. Brown ML, McKellar SH, Sundt TM, Schaff HV. Ministernotomy versus conventional sternotomy for aortic valve replacement: a systematic review and meta-analysis. J Thorac Cardiovasc Surg 2009; 137: 670-679.

3. Bonacchi M, Prifti E, Giunti G, Frati G, Sani G. Does ministernotomy improve postoperative outcome in aortic valve operation? A prospective randomized study. Ann Thorac Surg 2002; 73: 460-465.

4. Kaczmarczyk M, Szałański P, Zembala M, Filipiak K, Karolak W, Wojarski J, Garbacz M, Kaczmarczyk A, Kwiecień A, Zembala M. Minimally invasive aortic valve replacement - pros and cons of keyhole aortic surgery. Kardiochir Torakochir Pol 2015; 12: 103-110.

5. Liu J, Sidiropoulos A, Konertz W. Minimally invasive aortic valve replacement (AVR) compared to standard AVR. Eur J Cardiothorac Surg 1999; 16 (Suppl. 2): $S 80-S 83$.
6. Litwinowicz R, Bryndza M, Chrapusta A, Kobielska E, Kapelak B, Grudzień G. Hyperbaric oxygen therapy as additional treatment in deep sternal wound infections - a single center's experience. Kardiochir Torakochir Pol 2016; 13: 198-202.

7. Furukawa N, Kuss O, Aboud A, Schönbrodt M, Renner A, Hakim Meibodi K, Becker T, Zittermann A, Gummert JF, Börgermann J. Ministernotomy versus conventional sternotomy for aortic valve replacement: matched propensity score analysis of 808 patients. Eur J Cardiothor Surg 2014; 46: 221-227.

8. Ranucci M, Frigiola A, Menicanti L, Castelvecchio S, Pistuddi V. Aortic crossclamp time, new prostheses, and outcome in aortic valve replacement. J Heart Valve Dis 2012; 21: 732-739.

9. Salis S, Mazzanti VV, Merli G, Salvi L, Tedesco CC, Veglia F, Sisillo E. Cardiopulmonary bypass duration is an independent predictor of morbidity and mortality after cardiac surgery. J Cardiothorac Vasc Anesth 2008; 22: 814-822.

10. Asimakopoulos G, Systemic inflammation and cardiac surgery: an update. Perfusion 2001; 16: 353-360.

11. Lund O. Valve replacement for aortic stenosis: the curative potential of early operation. Scand J Thorac Cardiovasc Surg Suppl 1993; 40: 1-137.

12. Filip G, Litwinowicz R, Kapelak B, Bryndza M, Bartus M, Konstanty-Kalandyk J, Ceranowicz P, Brzezinski M, Gafoor S, Bartus K. Patient-prosthesis mismatch after minimally invasive aortic valve replacement. Kardiol Pol 2018; 76: 908-910.

13. Bartuś K, Litwinowicz R, Kuśmierczyk M, Bilewska A, Bochenek M, Stąpór M, Woźniak S, Różański J, Sadowski J, Kapelak B. Primary safety and effectiveness feasibility study after surgical aortic valve replacement with a new generation bioprosthesis: one-year outcomes. Kardiol Pol 2018; 76: 618-624.

14. Ahmed I, House CM, Nelson WB. Predictors of inotrope use in patients undergoing concomitant coronary artery bypass graft (CABG) and aortic valve replacement (AVR) surgeries at separation from cardiopulmonary bypass (CPB). J Cardiothorac Surg 2009; 4: 24.

15. Royster RL. Myocardial dysfunction following cardiopulmonary bypass: recovery patterns, predictors of inotropic need, theoretical concepts of inotropic administration. J Cardiothorac Vasc Anesth 1993; 7 (4 Suppl 2): 19-25.

16. Lazar H, Buckberg G, Foglia R, Manganaro A, Maloney JJ. Detrimental effects of premature use of inotropic drugs to discontinue cardiopulmonary bypass. J Thorac Cardiovasc Surg 1981; 82: 18-25.

17. Szwerc MF, Benckart DH, Wiechmann RJ, Savage EB, Szydlowski GW, Magovern Jr GJ, Magovern JA. Partial versus full sternotomy for aortic valve replacement. Ann Thorac Surg 1999; 68: 2209-2213.

18. Litwinowicz R, Bartus K, Drwila R, Kapelak B, Konstanty-Kalandyk J, Sobczynski R, Wierzbicki K, Bartuś M, Chrapusta A, Timek T. In-hospital mortality in cardiac surgery patients after readmission to the intensive care unit: a single-center experience with 10,992 patients. J Cardiothorac Vasc Anesth 2015; 29: 570-575.

19. Pappalardo F, Franco A, Landoni G, Cardano P, Zangrillo A, Alfieri O. Longterm outcome and quality of life of patients requiring prolonged mechanical ventilation after cardiac surgery. Eur J Cardiothorac Surg 2004; 25: 548-552.

20. Doll N, Borger MA, Hain J, Bucerius J, Walther T, Gummert JF, Mohr FW. Minimal access aortic valve replacement: effects on morbidity and resource utilization. Ann Thorac Surg 2002; 74: 1318-1322.

21. Litwinowicz R, Konstanty-Kalandyk J, Goralczyk T, Bartus K, Mazur P. Dabigatran level monitoring prior to idarucizumab administration in patients requiring emergent cardiac surgery. J Thromb Thrombolysis 2018; 45: 9-12.

22. Plicner D, Mazur P, Hymczak H, Stoliński J, Litwinowicz R, Drwiła R, Undas A. Preoperative platelet aggregation predicts perioperative blood loss and rethoracotomy for bleeding in patients receiving dual antiplatelet treatment prior to coronary surgery. Thromb Res 2015; 136: 519-525.

23. Lee JW, Lee SK, Choo SJ, Song H, Song MG. Routine minimally invasive aortic valve procedures. Cardiovasc Surg 2000; 8: 484-490.

24. Corbi P, Rahmati M, Donal E, Lanquetot H, Jayle C, Menu P, Allal J. Prospective comparison of minimally invasive and standard techniques for aortic valve replacement: initial experience in the first hundred patients. J Cardiac Surg 2003; 18: 133-139.

25. Bartus K, Podolec J, Lee R, Kapelak B, Sadowski J, Bartus M, Oles K, Ceranowicz P, Trabka R, Litwinowicz R. Atrial natriuretic peptide and brain natriuretic peptide changes after epicardial percutaneous left atrial appendage suture ligation using LARIAT device. J Physiol Pharmacol 2017; 68: 117-123. 